Document downloaded from:

http://hdl.handle.net/10251/121108

This paper must be cited as:

Kasper, AC.; Veit, HM.; García Gabaldón, M.; Pérez-Herranz, V. (2018). Electrochemical study of gold recovery from ammoniacal thiosulfate, simulating the PCBs leaching of mobile phones. Electrochimica Acta. 259:500-509. https://doi.org/10.1016/j.electacta.2017.10.161

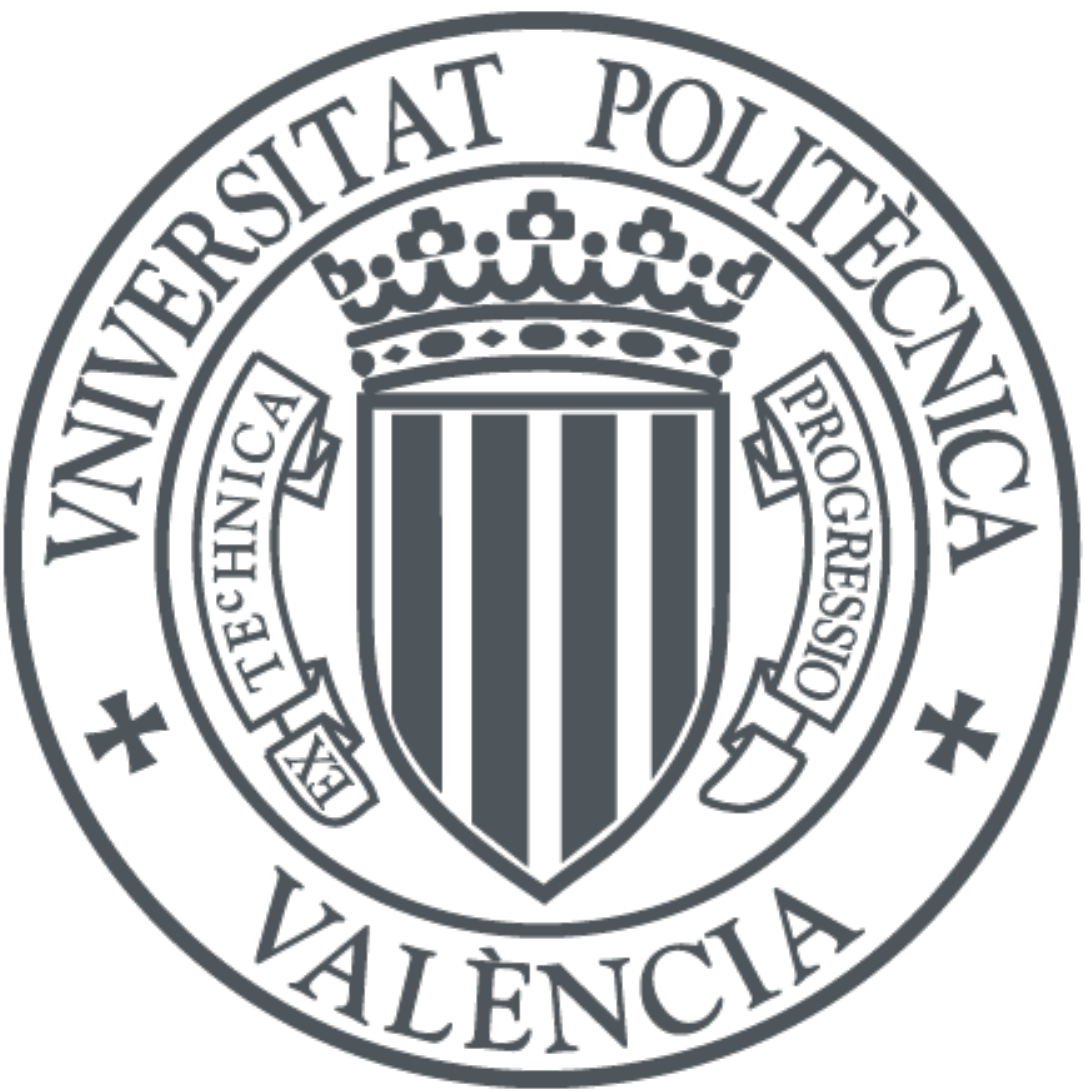

The final publication is available at

https://doi.org/10.1016/j.electacta.2017.10.161

Copyright Elsevier

Additional Information 


\section{Accepted Manuscript}

Electrochemical study of gold recovery from ammoniacal thiosulfate, simulating the PCBs leaching of mobile phones

Angela C. Kasper, Hugo M. Veit, Montserrat García-Gabaldón, Valentín Pérez Herranz

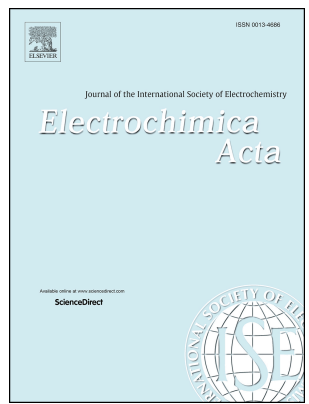

PII:

S0013-4686(17)32307-1

DOI:

10.1016/j.electacta.2017.10.161

Reference: $\quad$ EA 30547

To appear in: Electrochimica Acta

Received Date: 17 April 2017

Revised Date: 8 October 2017

Accepted Date: 25 October 2017

Please cite this article as: A.C. Kasper, H.M. Veit, M. García-Gabaldón, Valentí.Pé. Herranz, Electrochemical study of gold recovery from ammoniacal thiosulfate, simulating the PCBs leaching of mobile phones, Electrochimica Acta (2017), doi: 10.1016/j.electacta.2017.10.161.

This is a PDF file of an unedited manuscript that has been accepted for publication. As a service to our customers we are providing this early version of the manuscript. The manuscript will undergo copyediting, typesetting, and review of the resulting proof before it is published in its final form. Please note that during the production process errors may be discovered which could affect the content, and all legal disclaimers that apply to the journal pertain. 


\title{
Electrochemical Study of Gold Recovery from Ammoniacal Thiosulfate, Simulating the PCBs Leaching of Mobile Phones.
}

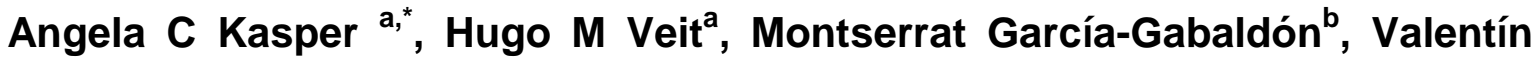 \\ Pérez Herranz ${ }^{\text {b }}$ \\ a LACOR-PPGE3M, Universidade Federal do Rio Grande do Sul, Av. Bento Gonçalves, 9500, \\ Setor 4, Prédio 43426, 91501-970 - Porto Alegre, Rio Grande do Sul, Brazil. \\ ${ }^{\mathrm{b}}$ Grupo IEC, Departamento de Ingeniería Química y Nuclear, Universitat Politècnica de València \\ , P.O. Box 22012, E-46071, Valencia, Spain
}

\begin{abstract}
The high volume of sales and the high degree of obsolescence of mobile phones, together with the reduction of the natural reserves of the metals used in the composition of their printed circuit boards (PCBs), makes the recycling of these devices economically and environmentally attractive. Moreover, the search for the reduction of toxicity levels inherent to the gold leaching processes with alternatives to cyanide, such as thiosulfate is a priority. Thus, it is necessary to search for efficient alternatives for the recovery of gold from solutions containing thiosulfate, in the presence of copper, used in the leaching of PCBs of mobile phones. One of these alternatives could be the electrochemical recovery of the metals present in solution. Thus, this study aimed to verify some variables involved in the process of recovery of gold and copper and to determine the electrochemical yield obtained for these solutions. Initially, cyclic scanning voltammetry with a rotating disk electrode (RDE) was performed to verify the electrochemical behavior of gold and
\end{abstract}

Corresponding author. Tel.: +55 513308 9425; fax: +55 5133089427.

E-mail address: angelakasper@globo.com (A. C. Kasper). 
copper in solution. Then, electrowinning tests were used to determine the recovery rates of these metals and to calculate the yield obtained in the process. The results showed that this electrochemical reaction is mass transport controlled, which allowed the calculation of the diffusion coefficients of the metal in solution. In real solutions, the gold fraction recovered reached a $94 \%$, and the copper fraction recovered was $95 \%$, applying electrode potential values of $-500 \mathrm{mV}_{\mathrm{Ag} / \mathrm{AgCl}}$ and $-700 \mathrm{mV}_{\mathrm{Ag} / \mathrm{AgCl}}$, respectively. The current efficiency for the gold electrowinning achieved in the experiments was lower than $3 \%$.

Keywords: Diffusion Coefficients; Electrowinning; Gold Recovery; Printed Circuit Board; Thiosulfate;

\section{INTRODUCTION}

Waste electrical and electronic equipment (WEEE) comprises a wide and varied range of equipment reaching the end of its useful life by default or obsolescence [1]. Among these devices, it is possible to highlight mobile phones, due to their high volume of sales and the high degree of obsolescence [2]. These devices, by their composition, can be considered important sources of metals of high economic interest (copper, nickel, silver, gold, palladium and others) as well as a source of hazardous metals (lead, cadmium and others) [3-5].

On devices such as mobile phones, a small incidence of corrosion may cause interruption or failure in operation. Thus, the presence of gold and its alloys becomes unavoidable due to their high resistance to corrosion and their high conductivity [6]. Although small amounts are used in each device, the precious metals have a significant economic importance in the EEE production. According 
to Hagelüken \& Corti (2010) [7], these metals can make up more than $80 \%$ of the value of a mobile phone. Regarding the quantities of gold present in the PCBs of mobile phones, some authors report that, depending on the model analyzed, the concentrations may exceed $300-350 \mathrm{~g} / \mathrm{t}$ [4, 8-11]. This means that the residues of these devices are significantly richer in gold than the primary ores of this metal, which contain on average of $5-10 \mathrm{~g} / \mathrm{t}[7,10-11]$.

Cyanide has been used for more than 100 years in the extraction of gold from ores and is currently also used in the extraction of gold from secondary sources due to its high efficiency and relatively low cost [12-15]. However, cyanide is highly toxic [16]. The reduction of acceptable levels for the discharge of cyanide into the environment has made that, in recent years, the world gold mining industry has turned its attention to the use of less toxic alternatives such as thiosulfate. Thiosulfate is a relatively inexpensive product and has low toxicity, making it an option that is economic and environmentally acceptable for the extraction of gold [17-20].

The recovery of metals of interest from leach liquors is an essential step in processing. Thus, the electrometallurgical recovery of metals has been the object of several studies, being considered an economically and environmentally attractive solution by several authors [21-31]. Currently, most of the copper, gold, nickel and zinc is processed, recovered, or refined by electrowinning [32-33].

While the electrowinning process of gold from cyanide solutions is a widely known process [28,34-35], the recovery of gold from copper ammoniacal thiosulfate solutions is more controversial. Some authors [36-37] consider this a problematic alternative due to the large amount of copper present in the solutions and also due to the reduction and oxidation reactions that involve the thiosulfate 
itself and that may interfere in the gold recovery process. However, other authors consider as a viable alternative route [23, 38-41].

Thus, the present study aims to evaluate the use of an electrochemical process to recover gold and copper from the thiosulfate solutions used in the leaching of printed circuit boards of mobile phones.

\section{MATERIALS AND METHODS}

\subsection{Solutions}

In this work, synthetic solutions containing thiosulfate, ammonia, copper and gold were used to perform the cyclic voltammetry experiments and electrowinning tests. The composition of these solutions was $100 \mathrm{ppm}$ of gold and $1000 \mathrm{ppm}$ of copper (that is, $100 \mathrm{~g} / \mathrm{t}$ of gold and $1000 \mathrm{~g} / \mathrm{t}$ of copper). This composition represents the mean of the value obtained in the extraction of gold from PCBs of mobile phones in our previous studies [9]. In relation to thiosulfate and ammonium, solutions containing $0.12 \mathrm{~mol} \mathrm{~L}^{-1}$ of sodium thiosulfate and 0.2 mol $\mathrm{L}^{-1}$ of ammonium hydroxide were used in this work. Our previous work has shown that these concentrations are adequate to leach the gold present in the PCBs of mobile phones. [9].

The reagents used were: gold (III) chloride $\left(\mathrm{AuCl}_{3}, 64.4 \% \mathrm{Au}\right.$, by Alfa Aesar, $\mathrm{GmbH}$ ), copper (II) sulfate $\left(\mathrm{CuSO}_{4} \cdot 5 \mathrm{H}_{2} \mathrm{O}\right.$, by Panreac), sodium thiosulfate $\left(\mathrm{Na}_{2} \mathrm{~S}_{2} \mathrm{O}_{3} \cdot 5 \mathrm{H}_{2} \mathrm{O}\right.$, by Panreac), ammonium hydroxide $\left(\mathrm{NH}_{4} \mathrm{OH}, 29 \%\right.$, by J. T. Baker), sodium hydroxide ( $\mathrm{NaOH}$, by Panreac), and hydrochloric acid $(\mathrm{HCl}$ by Panreac). 
First, a synthetic solution containing 1000 ppm of gold was prepared by dissolving gold (III) chloride in water and hydrochloric acid $(\mathrm{HCl})$, forming $\mathrm{HAuCl}_{4}$. This solution was packed in a dark bottle and stored in a cool and dry place to prevent its deterioration. Aliquots were removed from this solution for the voltammetric and electrowinning studies. The other solutions (copper and thiosulfate solutions) were prepared daily. The solutions used in these studies are shown in Table I.

\section{Table I}

All solutions were obtained from analytical grade reagents and prepared with distilled water. All the studies were performed at $\mathrm{pH} 10 \pm 0.1$ (controlled by pHmeter Q400AS Quimis, with glass electrode) and a room temperature.

\section{$2.2 \quad$ Voltammetric studies}

In this study, a conventional three-electrode cell was used (Figure 1a). A platinum rotating disc (RDE) enclosed in Teflon with a surface area of $0.078 \mathrm{~cm}^{2}$ was used as a working electrode. An electrode of $\mathrm{Ag} / \mathrm{AgCl}$ (in saturated $\mathrm{KCl}$ ) was used as the reference electrode, and a platinum electrode with a surface area 1 $\mathrm{cm}^{2}$ was used as counter electrode.

The experiments were carried out at rotation rates of $500,1000,1500$, 2000 and $2500 \mathrm{rpm}$. The polarization curves were obtained at a scan rate of 20 $\mathrm{mVs}^{-1}$. The potential range used in this study was +1500 to $-1500 \mathrm{mV}_{\mathrm{Ag} / \mathrm{AgCl}}$. 
The experiments were controlled using an Autolab PGSTAT20 potentiostat/galvanostat connected to a PC (Software GPES 4.9).

Before each experiment, the surface of the working electrode was mechanically polished (using alumina powder) and rinsed off with distilled water. The solutions were deoxygenated for 10 minutes with nitrogen. The atmosphere was maintained inert during the whole measurement to eliminate oxygen reduction as a cathodic reaction.

\subsubsection{Calculation of the diffusion coefficients}

The diffusion coefficients of the ions in solution were calculated using the Levich equation by the limiting current density [42].

$$
\mathrm{I}_{\mathrm{lim}}=0,621 n \mathrm{~F} v^{-1 / 6} \mathrm{D}_{\mathrm{j}}^{2 / 3} \omega^{1 / 2} \mathrm{C}
$$

The Levich equation shows that the limiting current density is proportional to the square root of the rotational speed of the electrode. Thus, in a process controlled by mass transport the graphical representation of the limiting current density versus the square root of the rotational speed of the electrode, for a given concentration, is a straight line that passes through the origin. From this slope, it is possible to estimate the diffusion coefficient of the reactant if the kinematic viscosity is known.

\subsection{Electrowinning tests}


The electrochemical reactor (Figure 1b) used in this work consisted of a $150 \mathrm{~mL}$ Pyrex glass. Two graphite electrodes were used as cathode and anode, and an electrode of $\mathrm{Ag} / \mathrm{AgCl}$ (in saturated $\mathrm{KCl}$ ) was used as reference electrode. Both the cathode and the anode had an effective area of $14.15 \mathrm{~cm}^{2}$.

\section{Figure 1}

Initially, the electrowinning tests were performed with solutions containing $100 \mathrm{ppm}$ of gold, and then with solutions containing $10 \mathrm{ppm}$ of gold. In both cases, the concentrations of the other components present in the solution were kept constant: copper $1000 \mathrm{ppm}$, thiosulfate $\left(\mathrm{Na}_{2} \mathrm{~S}_{2} \mathrm{O}_{3}\right) 0.12 \mathrm{~mol} \mathrm{~L}^{-1}$ and ammonium 0.2 $\mathrm{mol} \mathrm{L} \mathrm{L}^{-1}$.

The gold and copper concentrations in solutions were measured by atomic absorption spectrophotometry (AAS) with a Perkin-Elmer spectrophotometer model Analyst 100. For measuring the concentration of gold, a gold hollow cathode lamp at $242.8 \mathrm{~nm}$ wavelength, $0.2 \mathrm{~nm}$ spectral bandwidth and an operating current of $10 \mathrm{~mA}$ was used. For copper, a copper hollow cathode lamp at $218.2 \mathrm{~nm}$ wavelength, $0.2 \mathrm{~nm}$ spectral bandwidth and an operating current of 10 mA was used.

\subsubsection{Parameters evaluated in the electrowinning process}

A series of parameters such as the fraction of metal recovered $\left(\mathrm{X}_{\mathrm{Me}}\right)$, current efficiency $(\phi)$, productivity $(\rho)$ and the specific energy consumption $\left(E_{s}\right)$ were evaluated in order to study the feasibility of the electrowinning process. Equations 2-5 were used for the calculation of these parameters. 


$$
\begin{aligned}
& X_{M E}(t)=\frac{C_{M E}(0)-C_{M E}(t)}{C_{M E}(0)} \\
& \phi(t)=\frac{n F V\left(C_{M E}(0)-C_{M E}(t)\right)}{\int_{0}^{t} I(t) d t} 100 \\
& \rho(t)=\frac{60000 M\left(C_{M E}(0)-C_{M E}(t)\right)}{t}\left(\frac{m g}{L m i n}\right) \\
& E_{S}(t)=\frac{\int_{0}^{t} I(t) U(t) d t}{3600 M V\left(C_{M E}(0)-C_{M E}(t)\right)}\left(\frac{k W h}{k g}\right)
\end{aligned}
$$

were concentrations are in $\mathrm{molL}^{-1}$, current intensity in $\mathrm{A}$, volume in $\mathrm{L}$, voltage in $\mathrm{V}$ and time in s.

\section{RESULTS AND DISCUSSION}

\subsection{Electrochemical Study of Gold and Copper and Determination of the Diffusion Coefficients}

The electrochemical behavior of gold and copper present in solutions was evaluated by cyclic voltammetry. Initially, the electrochemical behavior of each metal (gold and copper) was analyzed separately and then the electrochemical behavior of these metals together simulating a real solution (considering only concentrations of gold, copper, ammonium and thiosulfate) was analyzed.

\subsubsection{Gold}


In relation to the electrochemical behavior of gold, it is important to note that the anion $\left[\mathrm{AuCl}_{4}{ }^{-}\right]$used in synthetic solutions can have acid or alkaline hydrolysis (equations 6 and 7) and may therefore dissociate, forming $\mathrm{Au}^{+3}$ and $\mathrm{Au}^{+1}[43]$.

$$
\begin{aligned}
& \mathrm{AuCl}_{4}^{-}+j \mathrm{OH}^{-}+k \mathrm{H}_{2} \mathrm{O} \rightleftharpoons \mathrm{AuCl}_{4-j-k}(\mathrm{OH})_{j}\left(\mathrm{H}_{2} \mathrm{O}\right)_{k}^{k-1}+(j+k) \mathrm{Cl}^{-} \\
& \mathrm{AuCl}_{4}^{-}+j \mathrm{OH}^{-} \rightleftharpoons \mathrm{AuCl}_{4-j}(\mathrm{OH})_{j}^{-}+j \mathrm{Cl}^{-}, \beta_{j 0}
\end{aligned}
$$

where $j$ and $k$ are the stoichiometric values.

At low $\mathrm{pH}(<4)$ the chlorocomplexes of gold are stables [44]. The addition of ammonium hydroxide $(0.2 \mathrm{M})$ in the $\mathrm{HAuCl}_{4}$ solution and the consequent raise of $\mathrm{pH}$ up to 10.0 (conditions used in this work) led to the formation of complexes of gold with ammonium $\left[\mathrm{Au}\left(\mathrm{NH}_{3}\right)_{4}\right]^{+3}$ and $\mathrm{Au}\left(\mathrm{NH}_{3}\right)^{+}[45]$. The equations corresponding to the electrochemical reduction are as follows:

$$
\begin{aligned}
& \mathrm{Au}\left(\mathrm{NH}_{3}\right)_{4}{ }^{+3}+2 \mathrm{e}^{-} \rightarrow \mathrm{Au}\left(\mathrm{NH}_{3}\right)^{+}+2 \mathrm{NH}_{3} \quad \mathrm{E} \stackrel{\circ}{=} 206 \mathrm{mV}(\mathrm{SHE})[46] \\
& \mathrm{Au}\left(\mathrm{NH}_{3}\right)^{+}+\mathrm{e}^{-} \rightarrow \mathrm{Au}^{0}+\mathrm{NH}_{3} \quad \mathrm{E} \stackrel{\circ=160 \mathrm{mV}}{(\mathrm{SHE})} \text { [47] }
\end{aligned}
$$

The cathodic polarization curves, which show the effect of the rotational speed of the RDE electrode on the reduction of gold in the ammoniacal medium, without thiosulfate, are shown in Figure 2. This figure also shows the graphical representation of the Levich equation.

\section{Figure 2}


In this case, the plateau of limiting current density shown corresponds to the mass transfer processes often observed for reduction of metal from complexes [48]. In Figure 2 two plateaus can be observed, one between 550 and 300 $\mathrm{mV}_{\mathrm{Ag} / \mathrm{AgCl}}$ corresponding to the reduction of $\mathrm{Au}^{+3} / \mathrm{Au}^{+1}$ and another at potentials between $-200 \mathrm{mV}_{\mathrm{Ag} / \mathrm{AgCl}}$ and $-1000 \mathrm{mV}_{\mathrm{Ag} / \mathrm{AgCl}}$ corresponding to the reduction of $\mathrm{Au}^{+1} / \mathrm{Au}^{0}$. This data is compatible with the literature data [49-50].

In this case, it was also possible to observe that the limiting current density increases with the increase of the rotation rate of the electrode. Through the graphical representation of the Levich equation, it is possible to verify that in both cases a straight line passing near the origin is obtained and that the current density, corresponding to the second plateau ( $\mathrm{i}_{\mathrm{L} 2}$ ), is greater than the first. These two circumstances demonstrate that the reduction of gold in ammoniacal medium occurs in two consecutive steps controlled by mass transport.

The diffusion coefficients calculated for solutions containing gold in ammoniacal medium, without thiosulfate, obtained in this study were $4.7 \times 10^{-10}$ $\mathrm{m}^{2} / \mathrm{s}$ for $\mathrm{Au}^{+1}$ and $1.8 \times 10^{-9} \mathrm{~m}^{2} / \mathrm{s}$ for $\mathrm{Au}^{+3}$. These values are consistent with the values found in the bibliography that present values of $7.5 \times 10^{-10} \mathrm{~m}^{2} / \mathrm{s}$ for $\mathrm{Au}^{+1}$ and $1.25 \times 10^{-9} \mathrm{~m}^{2} / \mathrm{s}$ for $\mathrm{Au}^{+3}[51]$.

The cathodic polarization curves that show the effect of the rotation rate of the RDE electrode on the reduction of gold in a medium containing thiosulfate and ammonia are presented in Figure 3. This figure also presents the graphical representation of the Levich equation. For this solution only one plateau is observed. The plateau ranges between -250 $\mathrm{mV}_{\mathrm{Ag} / \mathrm{AgCl}}$ and $-600 \mathrm{mV}_{\mathrm{Ag} / \mathrm{AgCl}}$, and 
may be due to the complex $\left[\mathrm{Au}\left(\mathrm{S}_{2} \mathrm{O}_{3}\right)_{2}{ }^{3-}\right]$ formed by the reaction between gold and thiosulfate.

\section{Figure 3}

During the process of gold leaching of PCB the complex of gold $(\mathrm{I}) /$ thiosulfate is rather formed over the complexes of gold with ammonia or chlorine because presents a greater stability in relation to the others. The order of the stability constants $(\log \beta)$ of these complexes is $\left[\mathrm{Au}\left(\mathrm{S}_{2} \mathrm{O}_{3}\right)_{2}{ }^{3-}\right]>\left[\mathrm{Au}\left(\mathrm{NH}_{3}\right)^{-2}\right]>$ $\left[\mathrm{AuCl}_{2}\right]$, with values of 26,19 and 9 , respectively. This reaction of gold with thiosulfate was evidenced by the occurrence of a single plateau in the voltametry. This data is also compatible with the literature according to the following reaction [52]:

$$
\left[\mathrm{Au}\left(\mathrm{S}_{2} \mathrm{O}_{3}\right)_{2}{ }^{3-}\right]+\mathrm{e}^{-} \rightarrow \mathrm{Au}+\left(\mathrm{S}_{2} \mathrm{O}_{3}\right)^{2-} \quad \mathrm{E}^{\circ}=153 \mathrm{mV} \text { (SHE) }(10)
$$

The diffusion coefficient calculated for solutions containing gold and thiosulfate in ammoniacal medium obtained in this study was $5.05 \times 10^{-10} \mathrm{~m}^{2} / \mathrm{s}$. This values is consistent with the values found in the bibliography that show 1.2 $\times 10^{-10} \mathrm{~m}^{2} / \mathrm{s}$ [53].

\subsubsection{Copper}

After analyzing the electrochemical behavior of gold in ammoniacal medium (with and without thiosulfate), the same type of analysis was carried out for the copper ions under the same conditions.

The corresponding equations of electrochemical reduction are [45]:

$$
\begin{array}{ll}
\mathrm{Cu}\left(\mathrm{NH}_{3}\right)_{4}{ }^{2+}+\mathrm{e}^{-}=\mathrm{Cu}\left(\mathrm{NH}_{3}\right)_{2}{ }^{+}+2 \mathrm{NH}_{3} & \mathrm{E}^{\circ}=100 \mathrm{mV}{ }_{(\mathrm{SHE})} \\
\mathrm{Cu}\left(\mathrm{NH}_{3}\right)_{2}{ }^{+}+\mathrm{e}^{-}=\mathrm{Cu}+2 \mathrm{NH}_{3} & \mathrm{E}^{\circ}=-239 \mathrm{mV}{ }_{(\mathrm{SHE})}
\end{array}
$$


The effects of the rotational speed of the RDE on the reduction of copper in ammoniacal medium, without thiosulfate, are shown in Figure 4. In the same figure the graphical representation of the Levich equation, that allowed the estimation of the diffusion coefficient of the copper ions, can be observed.

\section{Figure 4}

In this figure two plateaus can be observed, the first one between - 300 $\mathrm{mV}_{\mathrm{Ag} / \mathrm{AgCl}}$ and $-500 \mathrm{mV}_{\mathrm{Ag} / \mathrm{AgCl}}$, corresponding to the reduction of $\mathrm{Cu}^{+2} / \mathrm{Cu}^{+1}$, and the second one at more cathodic potential values than $-600 \mathrm{mV}$ Ag/AgCl, corresponding to the reduction of $\mathrm{Cu}^{+1} / \mathrm{Cu}^{0}$. Each of these plateaus present a limiting current density, typical of a mass transport controlled process.

As can be seen, the limiting current density increases with the increase of the rotation rate of the electrode. In addition, the limiting current density of the second plateau is approximately twice the current density of the first, which is in accordance with the two-step process of copper reduction. This result is confirmed by the Levich equation, since in both cases (first and second plateau) a straight line was obtained that passes through the origin, and the current density corresponding to the second plateau ( $\mathrm{i}_{\mathrm{L} 2}$ ) is double that the first. These two circumstances demonstrate that the reduction of $\mathrm{Cu}^{+2}$ in ammoniacal medium occurs in two consecutive steps controlled by mass transport.

The diffusion coefficients calculated for solutions containing copper in ammoniacal medium were $6.07 \times 10^{-10} \mathrm{~m}^{2} / \mathrm{s}$ for $\mathrm{Cu}^{+1}$ and $6.7 \times 10^{-10} \mathrm{~m}^{2} / \mathrm{s}$ for $\mathrm{Cu}^{+2}$. The value reputed in the literature was $4.9 \times 10^{-10} \mathrm{~m}^{2} / \mathrm{s}$ for $\mathrm{Cu}^{+2}[54-57]$.

In solutions containing copper and thiosulfate in ammoniacal medium is important to note that thiosulfate reacts with copper (II) ions and produces the 
complex copper(I)/thiosulfate. This reaction causes a reduction in the concentration of copper (II) [58-59]. The equations of the corresponding electrochemical reduction is shown ahead:

$$
\mathrm{Cu}\left(\mathrm{S}_{2} \mathrm{O}_{3}\right)_{3}^{-2}+\mathrm{e}^{-} \rightarrow \mathrm{Cu}^{0} \quad \mathrm{E}^{\circ}=-250 \mathrm{mV}{ }_{(\mathrm{SHE})}
$$

The cathodic polarization curves that show the effect of the rotational rate of the RDE on the reduction of copper in ammoniacal medium in the presence of thiosulfate and the graphical representation of the Levich equation are presented in Figure 5. In this figure is possible to observe the presence of a plateau concerning the reduction of $\mathrm{Cu}^{+1} / \mathrm{Cu}^{0}$ at potential values more cathodic than -600 $\mathrm{mV}_{\mathrm{Ag} / \mathrm{AgCl}}$

\section{Figure 5}

The diffusion coefficient for solutions containing copper and thiosulfate in ammoniacal medium obtained in this study was $4.9 \times 10^{-10} \mathrm{~m}^{2} / \mathrm{s}$. This value is consistent with the values found in the bibliography [54-57].

\subsubsection{Gold, Copper and Thiosulfate System}

After analyzing the electrochemical behavior of gold and copper ions in ammoniacal medium separately (with and without thiosulfate), the electrochemical behavior of both ions in the same solution containing thiosulfate was analyzed. Figure 6 shows the effect of the rotational rate of the RDE on the reduction of gold and copper in a solution containing thiosulfate and ammonia.

In this figure two plateau can be observed, one between -100 and -550 $\mathrm{mV}_{\mathrm{Ag} / \mathrm{AgCl}}$, corresponding to the reduction of $\mathrm{Au}^{+1} / \mathrm{Au}^{0}$, and the other plateau at 
more cathodic potential values than $-600 \mathrm{mV}_{\mathrm{Ag} / \mathrm{AgCl}}$, corresponding to the reduction of $\mathrm{Cu}^{+1} / \mathrm{Cu}^{0}$. This behavior shows that the electrodeposition of gold and copper, under these conditions, occurs in two different ranges of potential. It is also observed that in both cases the limiting current density increases with the increase of the rotation rate of the electrode, and the straight line obtained (see inset of Figure 6) passes very close to the origin and therefore follows the Levich equation for reactions controlled by mass transport [53].

\section{Figure 6}

The diffusion coefficients for solutions containing gold and thiosulfate in ammoniacal medium obtained in this study were $5.05 \times 10^{-10} \mathrm{~m}^{2} / \mathrm{s}$. These values are consistent with the values found in the bibliography.

\subsection{Electrowinning Results}

Previously, it was verified that gold and copper are reduced to their metallic state at different potential values, which makes the possible recovery of gold through the use of an electrochemical reactor, using suitable applied potentials.

For this purpose, several electrowinning tests were carried out at different electrode potentials selected from the cyclic voltammetric tests.

According to literature data $[7-8,10]$ and confirmed by the results shown in our previous article [9], the amount of gold present in the printed circuit boards of mobile phones is variable, depending on the type, model or year of the board. Therefore, the amount of gold present in the leached solution also varies (between $14.0-70.0 \mathrm{ppm})$. 
Thus, electrowinning of gold using $100 \mathrm{~mL}$ of synthetic solutions containing 100 (solution A) and 10 (solution B) ppm of gold was performed. Both solutions $(A$ and $B)$ contain sodium thiosulfate $\left(0.12 \mathrm{~mol} \mathrm{~L}^{-1}\right)$, ammonia $\left(0.2 \mathrm{molL}^{-}\right.$ $\left.{ }^{1}\right)$ and copper sulfate (1000 ppm).

The evolution of the gold fraction recovered $\left(\mathrm{X}_{\mathrm{Au}}\right)$ versus time for solutions containing gold and copper through the application of different electrode potentials is presented in Figure 7. It can be observed that $X_{A u}$ increases with time until reaching a maximum value at the end of the experiments.

For solution A (gold $100 \mathrm{ppm}$ ), it is observed that for the lowest cathodic potential $(-250 \mathrm{mV})$, the value of $\mathrm{X}_{\mathrm{Au}}$ is lower (approximately 0.90 ) than that reached at the potentials of $-400,-500$ and $-700 \mathrm{mV}$, approximately 0.99 . This behavior can be explained by the fact that at $-250 \mathrm{mV}$ the corresponding current density is below the limiting current density of gold. For more cathodic potential values, between -400 and $-700 \mathrm{mV}$, the current density obtained is close to the limiting current density and the fraction of gold recovered is therefore the same in all cases, considering that the limiting current density represents the maximum reaction rate.

For potentials of $-1000 \mathrm{mV}$, the gold recovery is faster than for potentials close to the limiting current density. This may be due to the fact that, at very cathodic potentials, co-deposition of copper along with gold occurs, in addition to the generation of a large amount of hydrogen. The hydrogen formed under these conditions could act as turbulence promoter near the electrode [60], increasing the mass transfer and making the gold fraction recovered larger. 
For solution B (10 ppm of gold), it can be observed that the fraction recovered increases more slowly. For an electrode potential of $-400 \mathrm{mV}_{\mathrm{Ag} / \mathrm{AgCl}}, \mathrm{X}_{\mathrm{Au}}$ reached a maximum value of 0.5 in 300 minutes, whereas for a potential of -500 $\mathrm{mV}_{\mathrm{Ag} / \mathrm{AgCl}}$, the value reached is 0.9 the the same time value.

\section{Figure 7}

With respect to the gold fraction recovered, a mathematical model can be proposed, since the electrowinning tests were carried out in a reactor that can be considered as a uniform closed reactor. For a reactor of this type, operating under limiting current density conditions, the concentration decreases exponentially with time according to Equation 17:

$$
C=C_{0} e^{-k a_{e} t}
$$

Thus, the fraction of gold recovered versus time is:

$$
\mathrm{X}_{\mathrm{Au}}=1-e^{-k a_{e} t}
$$

According to the mathematical model proposed for a closed reactor, and from the fitting of the experimental data it is possible to calculate the product k. $a_{e}$. This product is a fundamental design parameter for electrochemical reactors, in which the reaction is controlled by the mass transport. The values of $k \cdot a_{e}$ obtained for this study are presented in Table II. 


\section{Table II}

The results of $k . a_{e}$ are very similar for the potential values of $-400,-500$ and $-700 \mathrm{mV}$, as at these applied potential values, the current is close to the limiting value. For these values, an average value was estimated $\left(k \cdot a_{e}=0.0152\right.$ $\min ^{-1}$ ) and with this value it is possible to calculate $C$ and $X_{A u}$ from Equations 17 and 18 respectively.

The product of $\mathrm{k} \cdot \mathrm{a}_{\mathrm{e}}$ is an important parameter in the design equations for all the electrochemical reactors supporting a mass transport controlled reaction [61]. In practice, it is difficult to separate the values of these parameters: In the case of metal deposition under limiting current conditions, usually porous and roughened metal deposits occur, and thus the specific electrode area is increased. This also can affect the mass transport coefficient. On the other hand, the enhanced turbulence effect, due to hydrogen formation on the cathode, makes the mass transfer coefficient increase as the electrode potential is shifted towards more cathodic values or when the current density increases [62]. Hydrogen formation becomes an evident feature when observing the low values of the current efficiency obtained in Figure 9. This is the reason why is so difficult separate the term $\mathrm{k} \cdot \mathrm{a}_{\mathrm{e}}$ and makes difficult compare the mass transfer coefficient with the data reported in the literature.

On the other hand, the hydrodynamic conditions depend not only on the electrolyte agitation but also on the bubbles generated on the cathode surface under very cathodic currents that act as turbulence promoters. Therefore, the differences observed in table 2 are more likely due to the turbulence promoting action of the gases formed at different current regimes and not to the different agitation.

Figure 8 (a) shows the evolution of the gold concentration (for a initial gold concentration of $100 \mathrm{ppm}$ ) over time for an applied electrode potential of $-500 \mathrm{mV}$, 
along with the mathematical fit of the experimental data to equation 18. It can be verified that the model fits very well with the experimental data.

\section{Figure 8}

Comparing the results obtained in Figure 8 (b) with the results obtained in the cyclic voltammetry for the gold/copper/thiosulfate/ammonia system, it is verified that, in the majority of the potentials used, the results coincide with the expected results obtained in the polarization curves. However, a discrepancy between both tests can be observed when a potential of $-250 \mathrm{mV}$ is applied. According to the polarization curves using a potential of $-250 \mathrm{mV}$, we would already be working on the limiting current density for the case of gold; however, in the electrowinning tests the value of $\mathrm{X}_{\mathrm{Au}}$ obtained is lower (0.90) than in the potentials of $-400,-500$ and $-700 \mathrm{mV}(0.99)$. This difference can be explained by the difference in the assembly of the two experiments, such as the difference in the size of the electrodes used in the electrowinning, the nature of the electrodes, and the position of the reference electrode, among others.

Figure 9 shows the evolution of the current efficiency calculated versus time for the different electrode potentials.

It is verified that for the solutions containing $100 \mathrm{ppm}$ of gold (solution A) the current efficiency was inferior to $6 \%$ for all the cases, whereas for solutions containing $10 \mathrm{ppm}$ of gold (solution B), the electric efficiency was less than $1 \%$.

Figure 9 
As seen in our previous study [63], this low efficiency can be explained by the presence of copper in the solution. Even at potential values where there is no copper deposition, this species could contribute to the increase the current density. This increase in current density is probably due to the fact that copper favors the hydrogen evolution reaction (HER), which results in a low current efficiency of gold in the presence of copper.

Therefore, for solutions containing small amounts of gold (10 ppm) and large amounts of copper (1000 ppm), the less negative the potential applied, the lower the observed current efficiency.

As can be observed in the figure, the electrowinning of gold from solutions containing gold and copper, especially when the amount of copper is much higher than the amount of gold present in the solution, presented a low current efficiency, being below 3\%. However, according to the literature [64], the low current efficiency is not uncommon in the gold industry, which normally operates at current efficiencies below $10 \%$.

Figure 10 shows the evolution of the productivity (a) and the specific energy consumption (b) as a function of time, for the different electrode potentials tested, and for solutions containing $100 \mathrm{ppm}$ of gold.

It can be observed that the productivity curves are practically coincident. This is because in all cases the operates at, or close to, the limiting current density and this represents the maximum reaction velocity. On the other hand, the productivity decreases with time because gold is removed from solution. 


\section{Figure 10}

It is verified that the energy consumption increases with time and with the increase of the applied potential. This is quite logical, since with the passage of time the amount of gold ions in solution to be recovered decreases and the secondary reactions are gaining more and more weight in the system. On the other hand, the energy consumption increases with the potential because as the potential becomes more cathodic, the greater the total voltage is, and the higher the energy consumption. Moreover, the more cathodic the potential is, the greater the current intensity, which also contributes to the increased consumption of energy.

\section{CONCLUSIONS}

The results showed that for gold/copper/thiosulfate solutions, the deposition of copper occurs at potentials more negative than $-600 \mathrm{mV}_{\mathrm{Ag} / \mathrm{AgCl}}$, whereas the deposition of gold occurs in potentials more positive than -

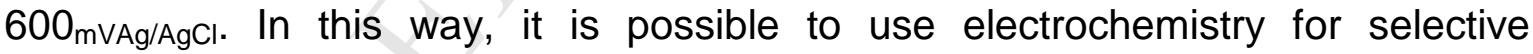
recovery of the two metals.

From the results obtained in the cyclic voltammetry with RDE, applying the Levich equation it is possible to verify that in both cases (gold and copper solutions in ammoniacal medium), a straight line passing near the origin is obtained. This circumstance demonstrates that the reduction of gold and copper in ammoniacal medium occurs in two consecutive steps controlled by mass 
transport. Thus, from these results, it was possible to estimate the diffusion coefficients of the ions in solution.

For solution A (100 ppm of gold) it is observed that for the least cathodic potential $(-250 \mathrm{mV})$ the value of $\mathrm{X}_{\mathrm{Au}}$ is lower (approximately 0.90 ) than that reached in the other potentials, where the evolutions of $\mathrm{X}_{\mathrm{Au}}$ with time are larger and similar (approximately 0.99 ). For solution B (10 ppm of gold) it can be observed that for solutions containing lower concentrations the fraction of gold recovered increases more slightly. In this case, for an electrode potential of -400 $\mathrm{mV}_{\mathrm{Ag} / \mathrm{AgCl}}, \mathrm{X}_{\mathrm{Au}}$ reached a maximum value of 0.5 in 300 minutes, whereas for a potential of $-500 \mathrm{mV}_{\mathrm{Ag} / \mathrm{AgCl}}$, the value reached 0.9 over the same period of time.

The results obtained in the electrochemical tests indicated that the presence of copper in the solution leads to an increase in the current density and that the system behaves according to the mathematical model proposed for a closed reactor.

The current efficiency achieved in the experiments with real solutions was low, less than $3 \%$. However, according to the literature, the gold industry normally operates at current efficiencies below $10 \%$.

In synthetic solutions the productivities almost coincide because in all cases they operate in limiting current densities. Productivity falls over time, as the rate of gold recovery slows over time. The energy consumption increases with time and with increase in applied potential. The increase in energy consumption over time occurs because, over time, the amount of gold ions in solution to be recovered decreases and the secondary reactions take more and more weight in the system. 


\section{Acknowledgments}

The authors would like to thank the Coordenação de Aperfeiçoamento de Pessoal de Nível Superior (CAPES) and Conselho Nacional de Desenvolvimento Cientifico e Tecnológico (CNPq) from Brazil for financial support.

\section{REFERENCES}

[1] Directive 2002/96/EC of the European Parliament and of the Council of 27 January 2003 on Waste Electrical and Electronic Equipment (WEEE). EEA, EEA, Waste from electrical and electronic equipment (WEEE), European Environment Agency, Copenhagen, 2003.

[2] Y.C. Jang; M. Kim; Management of used \& end-of-life mobile phones in Korea: A review. Resources, Conservation and Recycling 55, 11-19, 2010.

[3] M, Oguchi; S. Murakami; H. Sakanakura; A. Kida; T. Kameya; A preliminary categorization of end-of-life electrical and electronic equipment as secondary metal resources. Waste Management 31, 2150-2160, 2011.

[4] UNEP (United Nations Environmental Programme) \& UNU (United Nations University) Recycling - From e-waste to resources, Final report. Berlin, 2009.

[5] O. Tsydenova; M. Bengtsson; Chemical hazards associated with treatment of waste electrical and electronic equipment. Waste Management 31, 45-58, 2011.

[6] H. Renner; G. Schlamp; D. Hollmann; H. M. Lüschow; P. Tews; J. Rothaut; K. Dermann; A. Knödler; C. Hecht; M. Schlott; R. Drieselmann; C. Peter; R. Schiele; Gold, Gold Alloys, and Gold Compounds. Wiley-VCH Verlag GmbH \& Co. KGaA: Ullmann's Encyclopedia of Industrial Chemistry, 2000.

[7] C. Hageluken; C. W. Corti; Recycling of gold from electronics: Cost effective use through 'Design for Recycling'. Gold Bull. 43 (3), 209-220, 2010. 
[8] A. C. Kasper; G. B. T. Berselli; B. D. Freitas; J. A. S. Tenório; A. M. Bernardes; H. M. Veit; Printed wiring boards for mobile phones: Characterization and recycling of copper. Waste Management, 31, 2536-2545, 2011.

[9] A. C. Kasper; H. M. Veit; Study of Gold Leaching from Printed Circuit Boards Scraps of Mobile Phones. Unpublished results.

[10] P. Chancerel, C. E. M. Meskers; C. Hagelüken; V. S. Rotter; Assessment of precious metal flows during preprocessing of waste electrical and electronic equipment. Journal of Industrial Ecology, 13 (5), 791-810, 2009.

[11] UNEP (International Panel for Sustainable Resource Management, United Nations Environmental Programme). Metal Recycling - Opportunities, Limits, Infrastructure. Paris, 2013.

[12] J. Cui; L. Zhang; Metallurgical recovery of metals from electronic waste: A review. Journal of Hazardous Materials 158, 228-256, 2008.

[13] E-Y. Kim; M-S. Kim; J-C. Lee; B. D. Pandey; Selective recovery of gold from waste mobile phone PCBs by hydrometallurgical Process. Journal of Hazardous Materials 198, 206-215, 2011.

[14] S. Syed; Recovery of gold from secondary sources - A review. Hydrometallurgy 115-116, 30-51, 2012.

[15] A. Tuncuk; V. Stazi; A. Akcil; E. Y. Yazici; H. Deveci; Aqueous metal recovery techniques from e-scrap: Hydrometallurgy in recycling. Minerals Engineering 25, 28-37, 2012.

[16] U.S. DEPARTMENT OF HEALTH AND HUMAN SERVICES Public Health Service Agency for Toxic Substances and Disease Registry, Toxicological Profile For Cyanide, July, 2006.

[17] C. Abbruzzese; P. Fomari; R. Massidda; F. Veglió; S. Ubaldini; Thiosulphate leaching for gold hydrometallurgy. Hydrometallurgy, 39, 265-276, 1995. 
[18] M. I..Jeffrey; Kinetic aspects of gold and silver leaching in ammoniathiosulfate solutions. Hydrometallurgy, 60 (1): 7-16, 2001.

[19] M. G.Aylmore; D. M. Muir; W. P. Staunton; Effect of minerals on the stability of gold in copper ammoniacal thiosulfate solutions - The role of copper, silver and polythionates. Hydrometallurgy 143, 12-22, 2014.

[20] J.Y. Baron, J. Mirza, E.A. Nicol, S.R. Smith, J.J. Leitch, Y. Choi, J. Lipkowski; SERS and electrochemical studies of the gold-electrolyte interface under thiosulfate based leaching conditions; Electrochimica Acta 111, 390-399 , 2013.

[21] P. Fornari; C. Abbruzzese; Copper and nickel selective recovery by electrowinning from electronic and galvanic industrial solutions. Hydrometallurgy 52, 209-222, 1999.

[22] J. A. Harrison; J. Thompson; The electrodeposition of precious metals - a review of the fundamental electrochemistry. Electrochimica Acta, 18, 829-834, 1973.

[23] V. Reyes Cruz; M. T. Oropeza; I. Gonzalez; C. Ponce-De-León; Electrochemical recovery of silver from cyanide leaching solutions, Journal of Applied Electrochemistry 32, 473-479, 2002.

[24] F. Fourcade; T. Tzedakis; A. Bergel; Electrochemical process for metal recovery from iodized silver derivatives in liquid/solid mixture: Experimental and theoretical approaches. Chemical Engineering Science 58, 3507 - 3522, 2003.

[25] O. G. Gromov; A. P. Kuz'min; G. B. Kunshina; E. P. Lokshin; V. T. Kalinnikov; Electrochemical Recovery of Silver from Secondary Raw Materials. Russian Journal of Applied Chemistry, 77, 1, 62- 66, 2004.

[26] M. Garcia-Gabaldon; V. Perez-Herranz; J. Garcia-Anton; J. L. Guinon; Electrochemical recovery of tin and palladium from the activating solutions of the electroless plating of polymers - Potentiostatic operation, Separation and Purification Technology, 45(3), 183-191, 2005. 
[27] M. Garcia-Gabaldon; V. Perez-Herranz; J. Garcia-Anton; J. L. Guinon; Electrochemical recovery of tin from the activating solutions of the electroless plating of polymers - Galvanostatic operation. Separation and Purification Technology 51, 143-149, 2006.

[28] C. Y. Yap; N. Mohamed; An electrogenerative process for the recovery of gold from cyanide solutions. Chemosphere 67, 1502-1510, 2007.

[29] C. Peng; Y. Liu; J. Bi; H. Xu; A. Ahmed; Recovery of copper and water from copper-electroplating wastewater by the combination process of electrolysis and electrodialysis. Journal of Hazardous Materials 189, 814-820, 2011.

[30] J. Carrillo-Abad; M. García-Gabaldón; E. Ortega; V. Pérez-Herranz; Recovery of zinc from spent pickling solutions using an electrochemical reactor in presence and absence of an anion-exchange membrane: Galvanostatic operation. Separation and Purification Technology, 98, 366-374, 2012.

[31] H. M. Veit; A. M. Bernardes; J. Z. Ferreira; J. A. S. Tenório; C. F. Malfatti; Recovery of copper from printed circuit boards scraps by mechanical processing and electrometallurgy. Journal of Hazardous Materials B137, 1704-1709, 2006.

[32] M. L. Free; The fundamentals of electrometallurgy in aqueous media. JOM, 59 (5), 28-33, 2007.

[33] T. Oishi; K. Koyama; H. Konishi; M. Tanaka; J-C. Lee; Influence of ammonium salt on electrowinning of copper from ammoniacal alkaline solutions. Electrochimica Acta, 53, 127-132, 2007.

[34] E. Avci; Electrolytic recovery of gold from aqueous Solutions. Electrochimica Acta, 33 (10), 1263-1266. 1988.

[35] V. Reyes-Cruz; I. González; M.T. Oropeza; Electro-recovery of gold and silver from a cyanide leaching solution using a three-dimensional reactor. Electrochimica Acta 49, 4417-4423, 2004. 
[36] M. G. Aylmore; D. M. Muir; Thiosulfate leaching of gold - A review. Minerals Engineering, Vol. 14, 2, pp. 135-174, 2001.

[37] A. C. Grosse; G. D. Dicinoski; M. J. Shaw; P. R. Haddad; Leaching and recovery of gold using ammoniacal thiosulfate leach liquors (a review). Hydrometallurgy, 69, 1-21, 2003.

[38] A. R. Alonso; G. T. Lapidus; I. González; A strategy to determine the potential interval for selective silver electrodeposition from ammoniacal thiosulfate solutions. Hydrometallurgy 85, 144-153, 2007.

[39] A. R. Alonso; G. T. Lapidus; I. González; Selective silver electroseparation from ammoniacal thiosulfate leaching solutions using a rotating cylinder electrode reactor (RCE); Hydrometallurgy 92, 115-123, 2008.

[40] A. G. Zelinsky; Anode current on gold in mixed thiosulfate-sulfite electrolytes; Electrochimica Acta, 154, 315-320, 2015.

[41] A.G. Zelinsky, O.N. Novgorodtseva; Effect of thiourea on the rate of anodic processes at gold and graphite electrodes in thiosulfate solutions. Electrochimica Acta 109, 482- 488, 2013.

[42] V. G. Levich; Physicochemical Hydrodynamics; Prentice-Hall, New York, 1962.

[43] I. V. Mironov; E. V. Makotchenko The Hydrolysis of $\mathrm{AuCl}_{4}{ }^{-}$and the Stability of Aquachlorohydroxocomplexes of Gold(III) in Aqueous Solution. Journal Solution Chemistry 38, 725-737, 2009.

[44] J. Herrera Gallego, C.E. Castellano, A.J. Calandra And A.J. Arvia; The Electrochemistry of Gold in Acid Aqueous Solutions Containing Chloride lons Journal of Electroanalytical Chemistry., 66 207-230, 1975.

[45] L. H. Skibsted, J. Bjerrum. Studies on Gold Complex. II. The Equilibrium between Gold(I) and Gold(III) in the Ammonia Systen and Standard Potentials of 
the Couples Involving Gold, Diammimegold(I). Acta Chemica Scandinavica A, 28, 764-770, 1974.

[46] A. J. Bard, R. Parsons, R., and J. Jordan, Eds. Standard Potentials in Aqueous Solution, p. 313-320. IUPAC/Marcel Dekker, Inc., New York (1985).

[47] X. H. Wang. "Thermodynamic equilibrium calculations on gold/silver lixiviant systems relevant to gold extraction from complex ores." Proc.-Electrochem. Soc., 92-17 (Proc. Int. Symp. Electrochem. Miner. Met.Process. III, 3rd, 1992), 452-477, 1992.

[48] P. Bradley, S. Roy, D. Landolt, J. Chem. Soc., Faraday Trans. 92 (20), 4015, 1996.

[49] B. Lack; J. Duncan; T. Nyokong; Adsorptive cathodic stripping voltammetric determination of gold(III) in the presence of yeast mannan. Analytica Chimica Acta 385, 393-399, 1999.

[50] I. V. Mironov. Stability of Diammine and Chloroammine Gold(I) Complexes in Aqueous Solution. Russian Journal of Inorganic Chemistry, 52 (6), 960-962, 2007.

[51] M. A. Diaz; G. H. Kelsall and N. J. Welham; Electrowinning coupled to gold leaching by electrogenerated chlorine - I. $\mathrm{Au}(\mathrm{III})-\mathrm{Au}(\mathrm{I}) / \mathrm{Au}$ kinetics in aqueous $\mathrm{Cl}_{2} / \mathrm{Cl}^{-}$electrolytes. Journal of Electroanalytical Chemistry, 361, 25-38, 1993.

[52] B. J. Hiskey and V. P. Atluri. "Dissolution Chemistry of Gold and Silver in Different lixiviants." Mineral Processing and Extractive Metallurgy Review, 4: 95134, 1988.

[53] J-Liew, M.; Sobri, S.; Roy, S.; Characterisation of a thiosulphate-sulphite gold electrodeposition process. Electrochimica Acta 51, 877-881, 2005.

[54] J. Malyszko; M. Scendo,. Electrode kinetics of the $\mathrm{Cu}(\mathrm{II}) / \mathrm{Cu}(\mathrm{I})$ system at platinum in water + dimetilsulphoxide (DMSO) mixtures. J. Electroanal. Chem., 250, 61-72, 1988. 
[55] D. Pletcher; I. White; F. C. Walsh; J. P. Millington; Reticulated vitreous carbon cathodes for metal ion removal from process streams - Part I: Mass transport studies, Journal of Applied Electrochemistry. 21, 659-666, 1991.

[56] D. Grujicic; B. Pesic; Reaction and nucleation mechanisms of copper electrodeposition from ammoniacal solutions on vitreous carbon. Electrochimica Acta 50, 4426-4443, 2005.

[57] P. H. B Costa; Transferência de massa em reator eletroquímico de carbono vítreo reticulado. Dissertação de Mestrado. Universidade Federal de São Carlos; São Carlos, Brasil, 2010.

[58] P. M. H. Petter; H. M. Veit; A. M. Bernardes: Evaluation of gold and silver leaching from printed circuit board of cellphones. Waste Management, 34, 2, 475482, 2014.

[59] P. L. Breuer; M. I. Jeffrey; The reduction of copper(II) and the oxidation of thiosulfate and oxysulfur anions in gold leaching solutions. Hydrometallurgy 70 , 163-173, 2003.

[60] J.C. Bazan, J.M. Bisang, Electrochemical removal of tin from dilute aqueous sulfate solutions using a rotating cylinder electrode of expanded metal, Journal Applied Electrochemistry. 34, 501-506, 2004.

[61] M. García-Gabaldón, V. Pérez-Herranz, J. Garcia-Anton, J.L. Guiñón, Electrochemical recovery of tin and palladium from the activating solutions of the electroless plating of polymers. Potentiostat operation, Sep. Purif. Technol. 45 (2005) 183-191.

[62] J.C. Bazan, J.M. Bisang, Electrochemical removal of tin from dilute aqueous sulfate solutions using a rotating cylinder electrode of expanded metal, J. Appl. Electrochem. 34 (2004) 501-506.

[63] A. C. Kasper; J. Carrillo Abad; M. García Gabaldón; H. M. Veit; V. Pérez Herranz;. Determination of the potential gold electrowinning from an ammoniacal 
thiosulphate solution applied to recycling of printed circuit board scraps. Waste Management \& Research, Vol. 34(1) 47-57, 2016.

[64] G. P. O'Malley; Recovery of Gold from Thiosulfate Solutions and Pulps with Anion-Exchange Resins. Ph.D. thesis. Murdoch University, Perth, Australia, 2002.

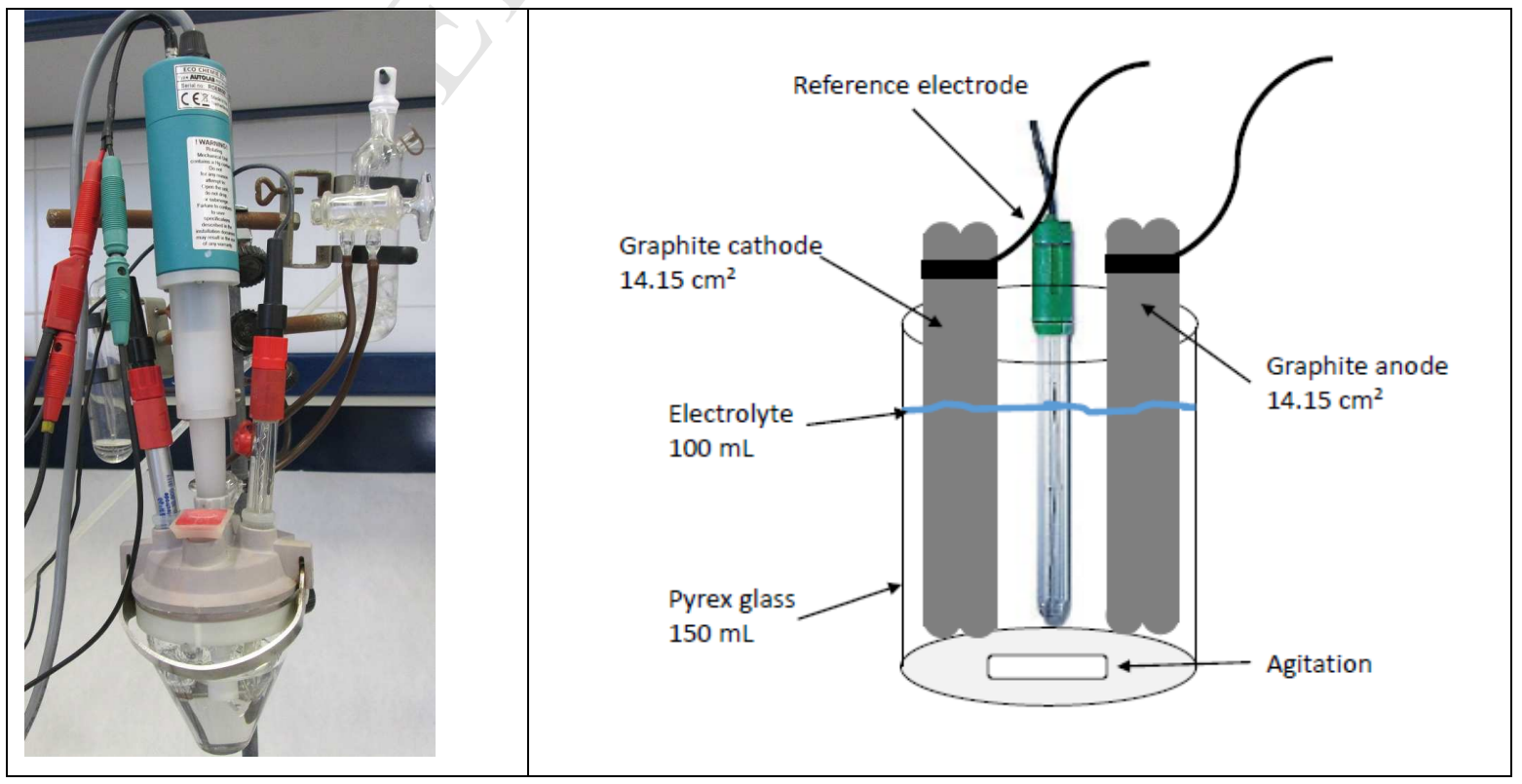


(a)

(b)

Figure 1: (a) Electrochemical cell used in the RDE study and (b) Diagram of the cell used in the electrowinning tests

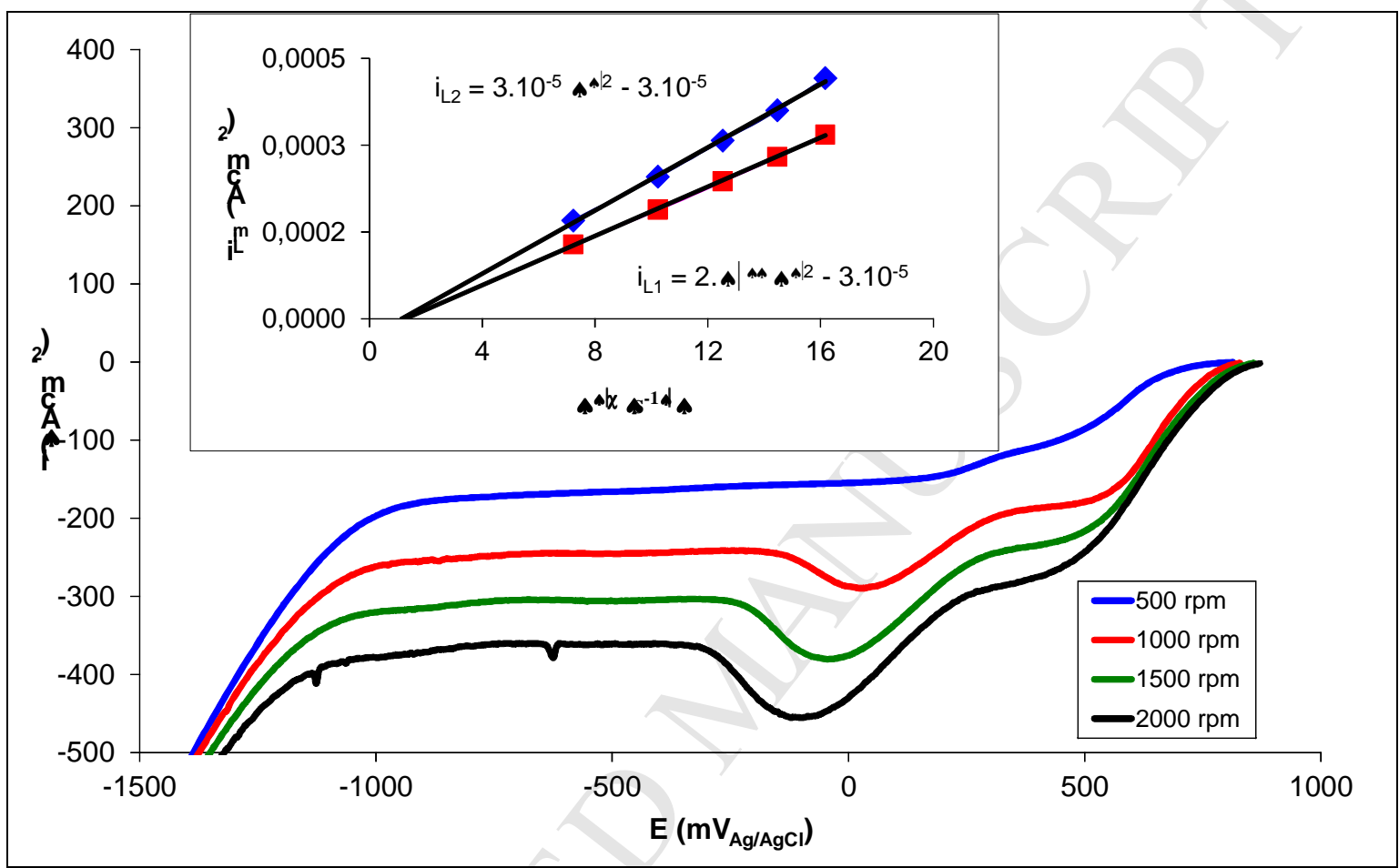

Figure 2: Cathodic polarization curves of the gold (100 ppm) in ammoniacal medium $(0.2$ mol $L^{-1}$ ), without thiosulfate, and graphical representation of Levich's equation ( $\omega$ is the rotation rate of the electrode). For a platinum working electrode (area of $0.078 \mathrm{~cm}^{2}$ ) and counter electrode of platinum.

Figure 3: Cathodic polarization curves of gold (100 ppm) and thiosulfate $\left(0.12 \mathrm{~mol} \mathrm{~L}^{-1}\right)$ in ammoniacal medium $\left(0.2 \mathrm{~mol} \mathrm{~L}^{-1}\right)$ and graphical representation of the Levich equation. For a platinum working electrode (area of $0.078 \mathrm{~cm}^{2}$ ) and counter electrode of platinum. 


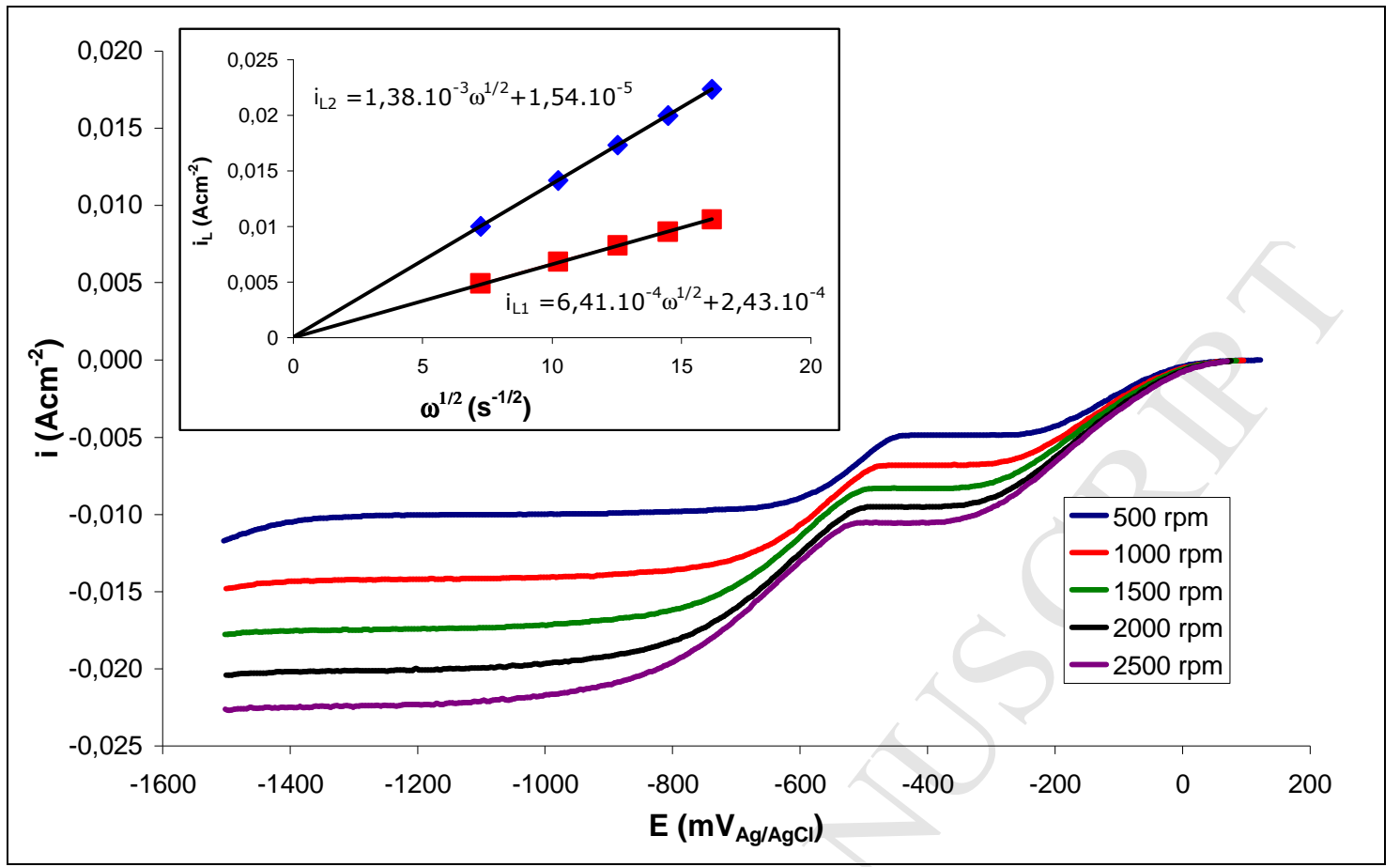

Figure 4: Cathodic polarization curves for copper $\left.\left(15 \mathrm{mmol} \mathrm{L}^{-1}\right)\right)$ in ammoniacal medium $\left(0.2 \mathrm{~mol} \mathrm{~L}^{-1}\right)$, without thiosulfate, and graphical representation of the Levich equation. For a platinum working electrode (area of $0.078 \mathrm{~cm}^{2}$ ) and counter electrode of platinum.

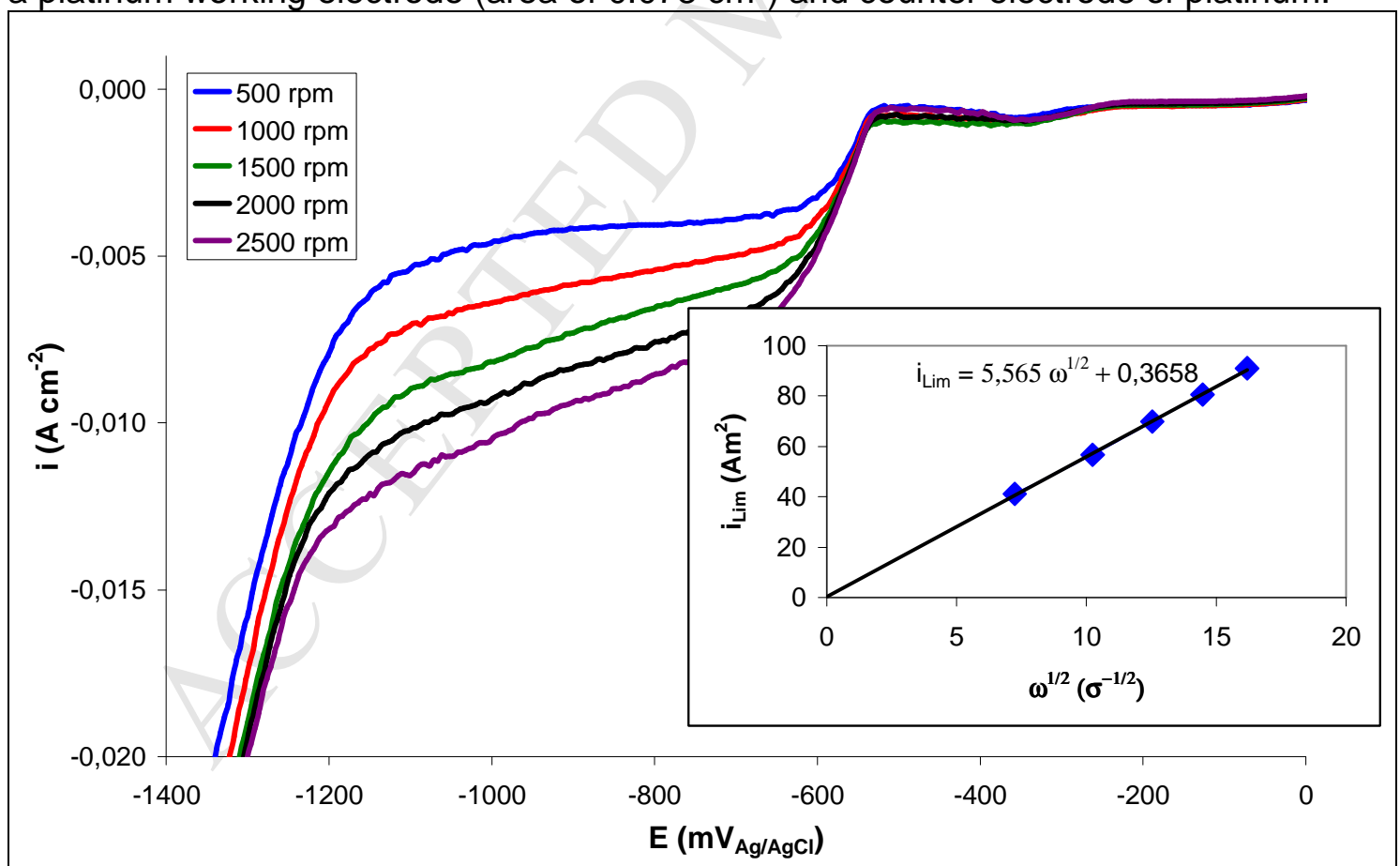

Figure 5: Cathodic polarization curves for copper $\left(15 \mathrm{mmol} \mathrm{L}^{-1}\right)$ with ammonia $\left(0.2 \mathrm{~mol} \mathrm{~L}^{-1}\right)$ in the presence of thiosulfate $\left(0.12 \mathrm{~mol} \mathrm{~L}^{-1}\right)$ and graphical representation of the Levich equation. For a platinum working electrode (area of $0.078 \mathrm{~cm}^{2}$ ) and counter electrode of platinum. 


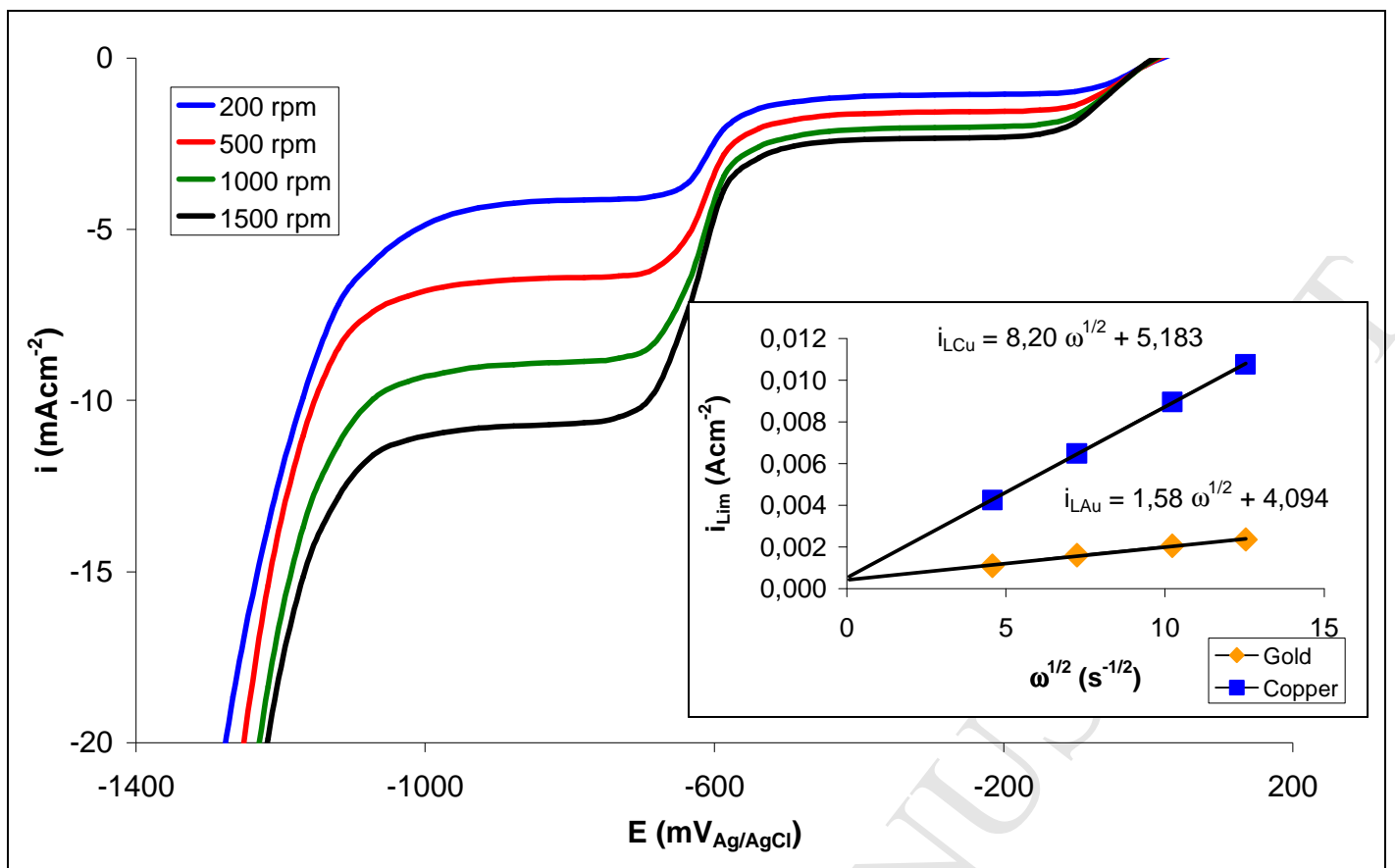

Figure 6: Cathodic polarization curves for gold (100 ppm), copper (1000 ppm) and thiosulfate $\left(0.12 \mathrm{~mol} \mathrm{~L}^{-1}\right)$ in ammoniacal medium $\left(0.2 \mathrm{~mol} \mathrm{~L}^{-1}\right)$ and graphical representation of the Levich equation. For a platinum working electrode (area of $0.078 \mathrm{~cm}^{2}$ ) and counter electrode of platinum.

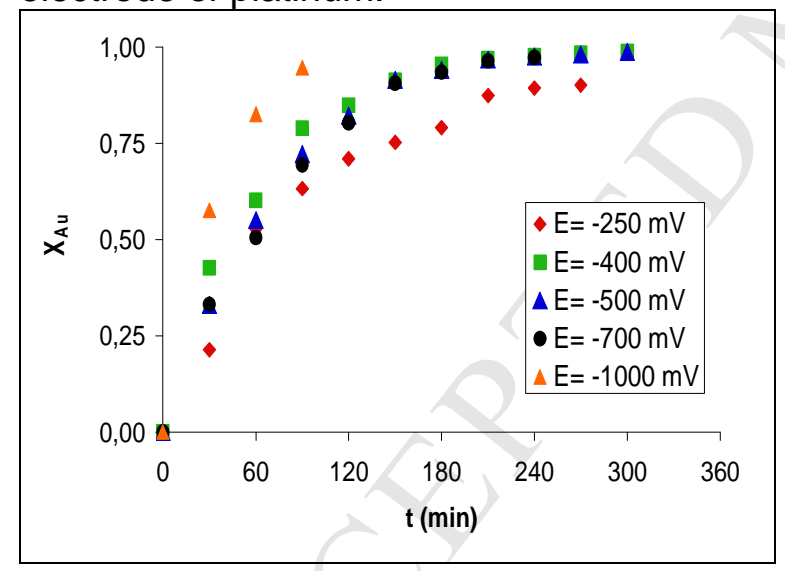

Solution A

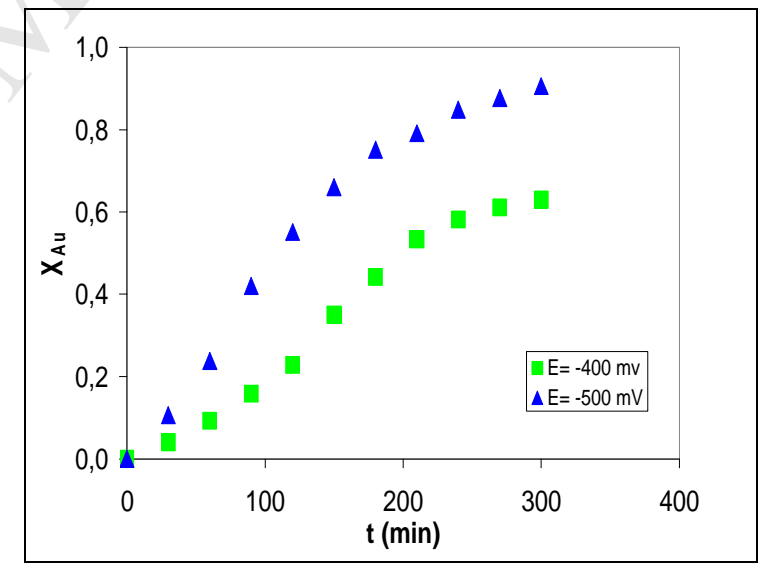

Solution B

Figure 7: Evolution of the gold fraction recovered versus time for solutions $A$ (100 ppm of gold $+1000 \mathrm{ppm}$ of Copper $\left.+0.12 \mathrm{~mol} \mathrm{~L}^{-1} \mathrm{Na2S} 2 \mathrm{O} 3+0.2 \mathrm{~mol} \mathrm{~L}^{-1} \mathrm{NH} 4 \mathrm{OH}\right)$ and $\mathrm{B}(10$ ppm of gold +1000 ppm of Copper $+0.12 \mathrm{~mol} \mathrm{~L}^{-1} \mathrm{Na2S} 2 \mathrm{O} 3+0.2 \mathrm{~mol} \mathrm{~L}^{-1} \mathrm{NH} 4 \mathrm{OH}$ ) 


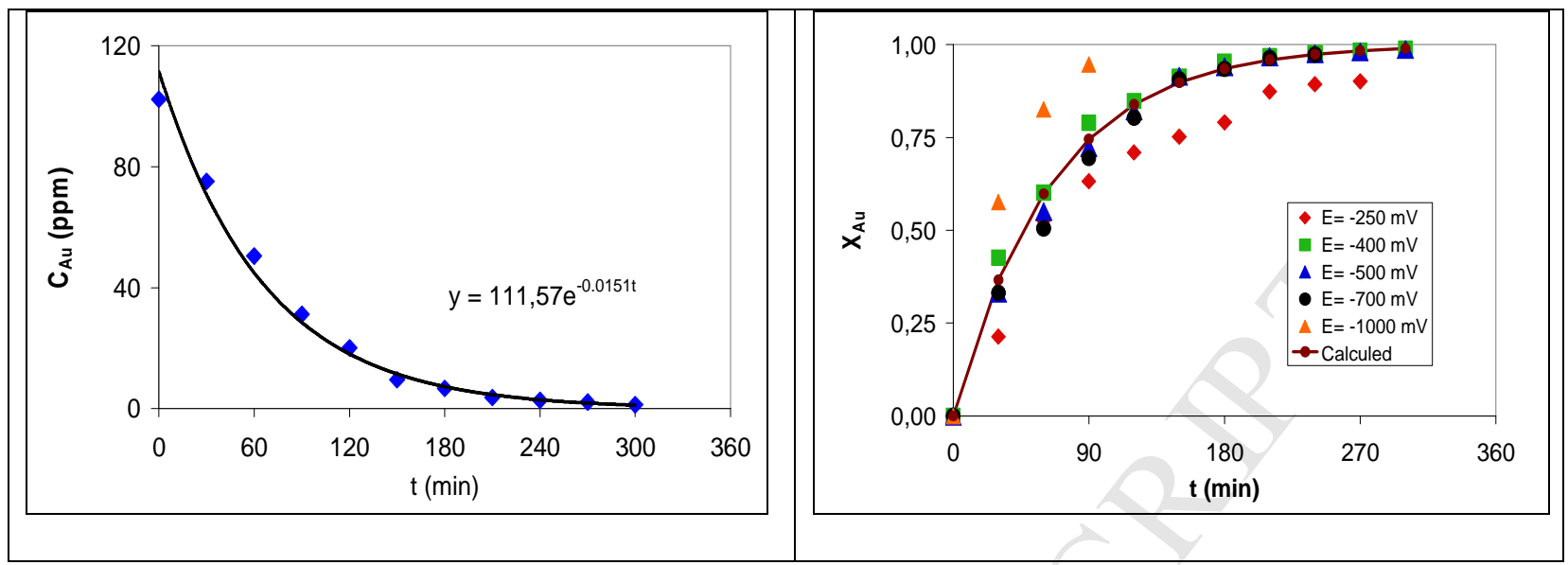

Figure 8: (a) Evolution of gold concentration over time at an applied potential of $-500 \mathrm{mV}$ (b) evolution of the gold fraction recovered over time

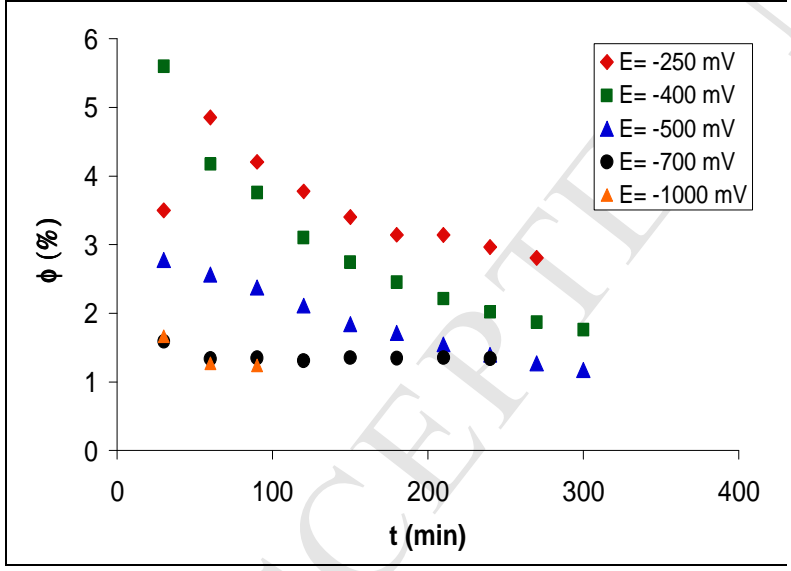

(a) Solution A

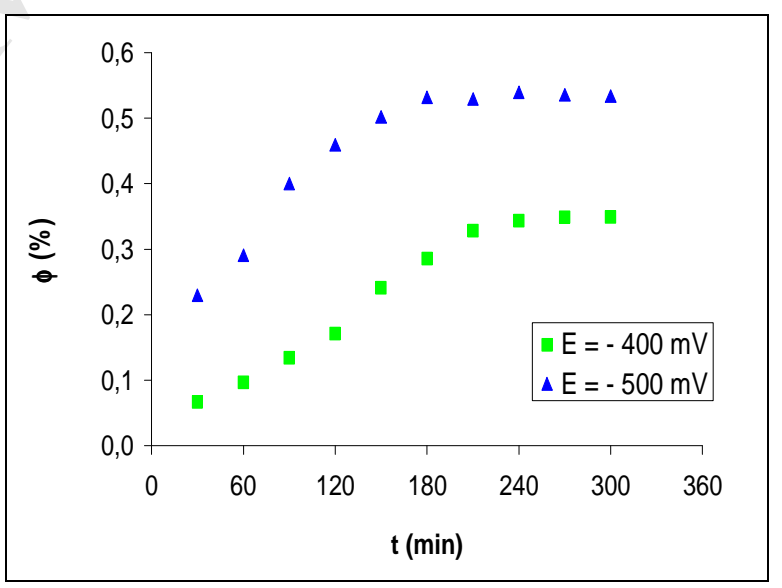

(b) Solution B

Figure 9: Comparison of the evolution of electric efficiency for solutions $A$ (100 ppm of gold $+1000 \mathrm{ppm}$ of Copper $\left.+0.12 \mathrm{~mol} \mathrm{~L}^{-1} \mathrm{Na2S} 2 \mathrm{O} 3+0.2 \mathrm{~mol} \mathrm{~L}^{-1} \mathrm{NH} 4 \mathrm{OH}\right)$ and $\mathrm{B}(10$ ppm of gold +1000 ppm of Copper $+0.12 \mathrm{~mol} \mathrm{~L}^{-1} \mathrm{Na2S} 2 \mathrm{O} 3+0.2 \mathrm{~mol} \mathrm{~L}^{-1} \mathrm{NH} 4 \mathrm{OH}$ ) 


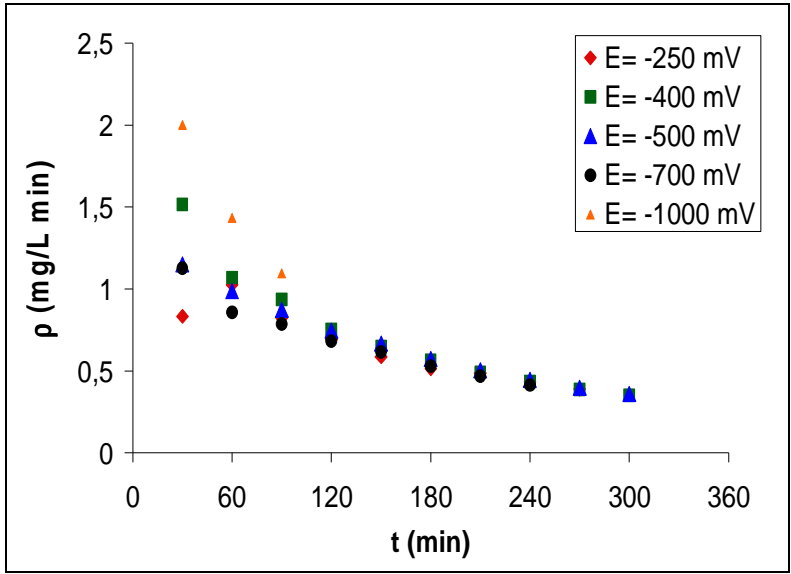

(a)

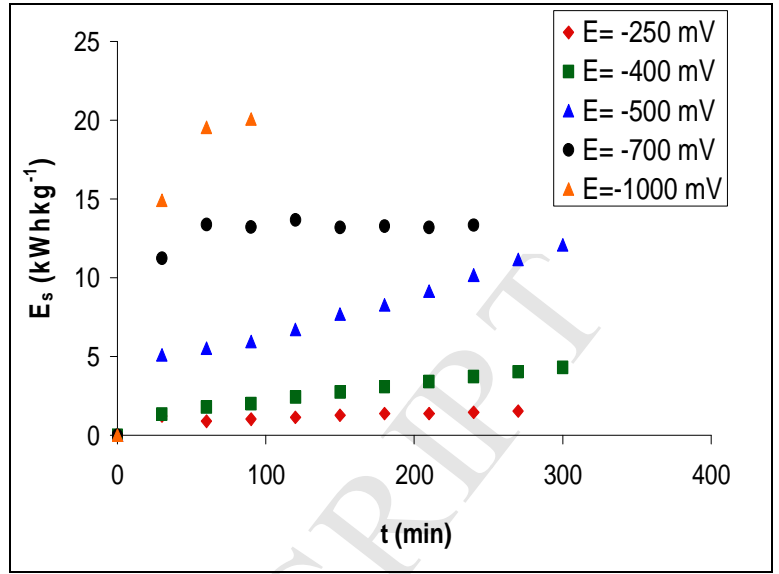

(b)

Figure 10: Comparison of the evolution (a) of productivity and (b) of specific energy consumption with time for different potentials

\begin{tabular}{|l|l|}
\hline \multicolumn{2}{|c|}{ Symbols } \\
\hline $\mathrm{a}_{\mathrm{e}}$ & Specific surface of the electrode \\
\hline$C$ & Concentration of the electroactive species in the solution $\left(\mathrm{mol} / \mathrm{m}^{3}\right)$ \\
\hline$C_{0}$ & Initial concentration \\
\hline $\mathrm{C}_{\mathrm{ME}}(0)$ & Initial concentration of the metal in solution \\
\hline $\mathrm{C}_{\mathrm{ME}}(\mathrm{t})$ & Concentration of the metal over time \\
\hline $\mathrm{D}_{\mathrm{j}}$ & Diffusion coefficient of the metal ion $\left(\mathrm{m}^{2} / \mathrm{s}\right)$ \\
\hline $\mathrm{E}_{\mathrm{s}}(\mathrm{t})$ & Specific energy consumption \\
\hline $\mathrm{F}$ & Faraday Constant $(\mathrm{C} / \mathrm{mol})$ \\
\hline $\mathrm{I}$ & Current intensity (A) \\
\hline $\mathrm{k}$ & Mass transfer coefficient \\
\hline
\end{tabular}




\begin{tabular}{|l|l|}
\hline $\mathrm{n}$ & Number of electrons involved in the redox reaction \\
\hline $\mathrm{t}$ & Time \\
\hline $\mathrm{V}$ & Volume of solution \\
\hline $\mathrm{X}_{\mathrm{ME}}(\mathrm{t})$ & Metal fraction deposited in function of time \\
\hline Greek letters & \\
\hline $\mathrm{v}$ & Kinematic viscosity of the medium $\left(\mathrm{m}^{2} / \mathrm{s}\right)$ \\
\hline$\rho$ & Productivity in function of time \\
\hline$\phi$ & Electric efficiency \\
\hline$\omega$ & Rotation rate of the electrode $\left(\mathrm{s}^{-1}\right)$ \\
\hline $\int_{0}^{t} I(t) d t$ & Integral of the current density by time \\
\hline
\end{tabular}

Table I: List of solutions used in the tests performed in this paper

\begin{tabular}{c|c}
\hline Study & Solutions \\
\hline Voltammetry 1 & $\mathrm{Au}+\mathrm{NH}_{4} \mathrm{OH}$ \\
Voltammetry 2 & $\mathrm{Au}+\mathrm{Na}_{2} \mathrm{~S}_{2} \mathrm{O}_{3}+\mathrm{NH}_{4} \mathrm{OH}$ \\
Voltammetry 3 & $\mathrm{Cu}+\mathrm{NH}_{4} \mathrm{OH}$
\end{tabular}




\begin{tabular}{c|l}
\begin{tabular}{c|c} 
Voltammetry 4 \\
Voltammetry 5
\end{tabular} & $\mathrm{Cu}+\mathrm{Na}_{2} \mathrm{~S}_{2} \mathrm{O}_{3}+\mathrm{NH}_{4} \mathrm{OH}$ \\
Electrowinning (A and B) & $\mathrm{Au}+\mathrm{Cu}+\mathrm{Na}_{2} \mathrm{~S}_{2} \mathrm{O}_{3}+\mathrm{NH}_{4} \mathrm{OH}$ \\
&
\end{tabular}

Table II: Values of $k \cdot a_{e} \times$ potentials calculated

\begin{tabular}{c|c}
\hline$E(\mathrm{mV})$ & $\mathrm{k} \cdot \mathrm{a}_{\mathrm{e}}\left(\mathrm{min}^{-1}\right)$ \\
\hline-250 & 0.0870 \\
\hline-400 & 0.0152 \\
\hline-500 & 0.0151 \\
\hline-700 & 0.0152 \\
\hline
\end{tabular}




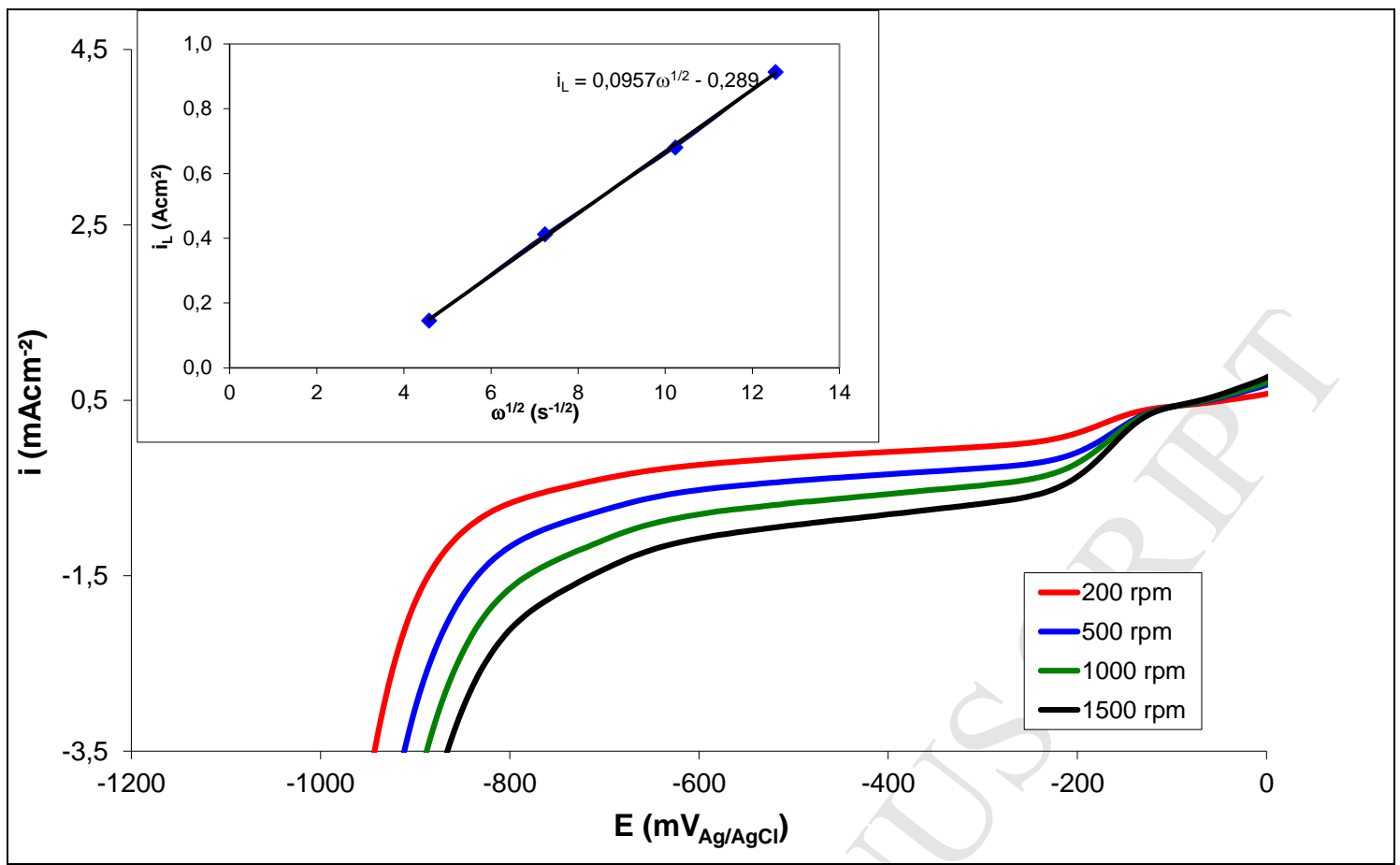

Figure 3: Cathodic polarization curves of gold (100 ppm) and thiosulfate $\left(0.12 \mathrm{~mol} \mathrm{~L}^{-1}\right)$ in ammoniacal medium $\left(0.2 \mathrm{~mol} \mathrm{~L}^{-1}\right)$ and graphical representation of the Levich equation. For a platinum working electrode (area of $0.078 \mathrm{~cm}^{2}$ ) and counter electrode of platinum. 